\title{
Effect of dietary administration of carrageenan on growth, survival and feed utilization of common carp, cyprinus carpio
}

\begin{abstract}
The efficiency of carrageenan as immunostimulant on growth, survival and feed utilization of common carp, Cyprinus carpio was evaluated. Carrageenan was incorporated at $0.5 \%$ and $1.0 \%$ in a $30 \%$ protein diet, while basal diet without supplementation of carrageenan served as control. The experimental diets were fed to fingerlings for 60 days in fiberglass tanks. The diets were given twice daily at a rate of 5\% of body weight during the first 15 days and reduced to $3 \%$ later on. Common carp fed $1 \%$ carrageenan supplemented diet showed relatively better growth in terms of specific growth rate, feed utilization, protein efficiency ratio and food conversion rate and survival
\end{abstract}

Keywords: Carrageenan, Immunostimulant, Growth, Survival, Cyprinus carpio
Volume 5 Issue I - 2017

\author{
Shivananda Murthy H, Shrikala D, Prakash \\ Patil , Shankar R \\ Department of Aquaculture, College of Fisheries, India
}

Correspondence: Shivananda Murthy H, Department of Aquaculture, College of Fisheries, KVAFSU, India, Email hsmurthy05@yahoo.com

Received: June 05, 2016 | Published: January 05, 2017

\section{Introduction}

Aquaculture industry is gaining a lot of importance globally, more so in the developing countries. Aquaculture has shown considerable advancement in the past decade due to a steady increase in demand for aquatic organisms. Recent years have witnessed the stagnation in landings from capture fisheries, hence aquaculture offers a potential source of fish production to meet the current and future demands of fish and shellfish. It has been found that fish in a human diet is known to reduce the risk of cardiovascular diseases and also provide protection against renal diseases, thus it has medical and therapeutic significance. Further, fish protein has also got special significance in human nutrition since it contains all essential amino acids, vitamins, minerals and polyunsaturated fatty acids. The increased need and demand for dietary protein for human consumption can meet partially from aquatic sources such as fish and shellfish. This has led to the intensification of culture of fish and shrimp in several parts of the world and the success of fish culture depends on several management measures. Among the several measures, artificial feeding has been considered as the most important because the optimum amount of food with well balanced nutrients (protein, carbohydrate, fat, minerals and vitamins) is required to achieve maximum production.

Due to gradual reduction of water bodies and consequent shifting towards intensive system of culture practices will likely to increase incidences of diseases. The fish diseases will cause considerable economic loss in aquaculture by reducing production and increasing the production costs. Considering the above facts, one of the preventive measures is incorporation of immunostimulants in fish diet to enhance their immune system. In fact, immunostimulants are the chemicals, drugs, stressor that elevates the non-specific defense mechanism or specific immune response. The use of immunostimulants has become an important aspect in fish culture recently for improving the fish production. Several fish food manufacturers in Europe now offer diets supplemented with immunostimulants for use in salmonid culture. Most of the immunostimulants are the molecules that are derived from microbial sources such as peptidoglycans, $\beta$-glucans and lipopolysaccharides have successfully used to initiate a series of non-specific defense activities. Carrageenan is a family of linear sulphated polysaccharides extracted from red seaweeds and is available in the form of powder in different forms. Carrageenan is used as an ingredient in diets to provide the phospholipids needed by various species of aquatic animals and to impart proper physical characteristics to the animals. ${ }^{1-4}$

Common carp, Cyprinus carpio is a widely cultured freshwater fish native to Asia and Eastern Europe. It is capable of interbreeding in captivity and found suitable for polyculture with Indian major carps. However, they are also used in monoculture particularly by small and artisan farmers in rural aqua farming. This carp is an omnivorous, feeds on detritus and other wastes (aquatic vegetation) in nature. The advantage of common carp over the other carp species that too in a tropical country like India is, they can be bred almost throughout the year, it has a shorter generation time and readily accepts pellet feeds. Common carp is found to grow much faster than the major carps rohu and mrigal but, its growth is almost equal to that of catla.

\section{Material and methods}

\section{Experimental animals}

Cyprinus carpio, Common carp fry procured from a Government Fish Seed Farm at the Bhadra Reservoir Project in Shivamogga, to the fish farm of the College of Fisheries in Mangaluru, were acclimatized to the pellet diet containing $30 \%$ protein for a period of two months.

\section{Formulation, preparation of experimental diets}

Experimental diets were prepared incorporating carrageenan at two graded levels namely $0.5\left(\mathrm{~T}_{1}\right)$ and $1 \%\left(\mathrm{~T}_{2}\right)$. Diet without carrageenan served as control $\left(\mathrm{T}_{0}\right)$. The basal diet with a crude protein content of $30 \%$, using fish meal and groundnut cake as major protein sources was formulated by employing Square Method. ${ }^{5}$ All the diets were analyzed for proximate composition according to AOAC. ${ }^{6}$ Moisture content was estimated by heating samples at $105^{\circ} \mathrm{C}$ for 30 minutes and then cooled and weighed till a constant weight was obtained. Crude protein was analyzed using Kjeltec system, fat content by Soxtech system and fiber content using Fibretech system. Nitrogen free extractives (NFE) was calculated by the difference method. ${ }^{7}$ 


\section{Experimental system}

The experiment was carried out in fibre-glass aquarium tanks measuring $1.25 \times 0.5 \times 0.5 \mathrm{~m}$ at the indoor aquaculture system of the College of Fisheries, Mangaluru. The aquaria were cleaned and filled with water from a nearby perennial open well. Uniform sized common carp fry $(0.36 \mathrm{~g})$ were stocked at a rate 15 numbers per aquaria in three replicate groups. They were fed twice daily at the rate of $5 \%$ of the body weight during the first 15 days and 3\% ther after. Unconsumed feed was siphoned out daily in the morning before offering the feed. After every sampling, the amount of feed given was adjusted based on the weight increase of the fish.

\section{Water quality analysis}

Water from experimental tanks was analyzed for physic chemical parameters every week. A digital portable kit model CK 704 was used to record $\mathrm{pH}$ and temperature. Dissolved oxygen was estimated by Winkler's method. Total alkalinity, ammonia and free carbon dioxide were determined by Standard Methods. ${ }^{8}$ The evaporation loss and deterioration in water quality due to accumulation of metabolites was overcome by periodic partial exchange of water.

\section{Growth studies}

Fishes in each tank were sampled fortnightly and individually measured their weight and length. The growth performance of the experimental animals was assessed at the end by calculating weight gain and percentage of survival using the following formula.

$$
\begin{aligned}
& S G R=\frac{\text { Log final weight }(g)-\text { Log initialweight }(g)}{\text { Number of days }} \times 100 \\
& F C R=\frac{\text { Dry weight of feed given }(g)}{\text { Gain in wet weight of fish }(g)} \\
& \text { Survival }(\%)=\frac{\text { Final number of fish }}{\text { Initial number of fish }} \times 100 \\
& P E R=\frac{\text { Increment of body weight }(g)}{\text { protein intake }(g)}
\end{aligned}
$$

\section{Results and discussion}

\section{Proximate composition of experimental diets}

The proximate composition of the experimental diets fed to common carp fry is presented in Table 1 . All the diets had about $30 \%$ protein and the values of crude protein ranged from $29.45 \%$ in $\mathrm{T}_{2}$ to $29.94 \%$ in $\mathrm{T}_{1}$. Moisture content of diets ranged from $3.3 \%$ in $\mathrm{T}_{1}^{2}$ to $4.05 \%$ in $\mathrm{T}_{2}$, but crude fat levels were ranged from $2.3 \%$ in $\mathrm{T}_{0}$ to $3.75 \%$ in $\mathrm{T}_{2}$. Similarly, the crude fibre content of diets ranged from $11.5 \%$ in $\mathrm{T}_{0}$ to $21 \%$ in $\mathrm{T}_{2}$. Overall, the proximate composition results of the experimental diets indicated that there was no significant difference between the diets after incorporation of carrageenan.

\section{Water quality parameters}

During the experimental period, the water temperature ranged from 25.1 to $28.8^{\circ} \mathrm{C}$, pH from 6.1 to 7.6 , dissolved oxygen from 6.4 to $8.6 \mathrm{mg} / \mathrm{l}$, free carbon dioxide from 0.15 to $4.8 \mathrm{mg} / 1$, and total alkalinity from 32 to $65.7 \mathrm{mg} / \mathrm{l}$ of $\mathrm{CaCO}$. These water quality parameters recorded during the experimental period were found suitable and well within the range for common carp culture. Further, it also show that the incorporation of carrageenan in diet did not affect the culture water.

\section{Growth Studies}

Data on the growth, survival, food conversion ratio and protein efficiency ratio of common carp fed on the graded levels of carrageenan incorporated diets are given in Table 2. Highest growth in terms of specific growth rate was observed in $1 \%\left(\mathrm{~T}_{2}\right)$ carrageenan incorporated diet fed common carp, compared to $\mathrm{T}_{0}$ and $\mathrm{T}_{1}$. However, highest survival $(76.5 \%)$ and PER $(0.06)$ were recorded for $\mathrm{T}_{1}$ treatment but, lower FCR of 2.5 was recorded in treatment, $\mathrm{T}_{0}$. Further, it was observed that there were no significant differences between experimental groups in survival and PER, but there were significant differences in SGR and FCR of treatments.

Table I Proximate composition of test diets (Mean \pm SD)

\begin{tabular}{llll}
\hline Components & Diets & & \\
\hline Moisture (\%) & $\mathbf{T}_{0}$ & $\mathbf{T}_{\mathbf{1}}$ & $\mathbf{T}_{\mathbf{2}}$ \\
Dry matter (\%) & $3.45+0.21$ & $3.3+0.24$ & $4.05+0.19$ \\
Crude protein (\%) & $96.55+0.23$ & $96.7+0.12$ & $95.95+0.21$ \\
Crude fat (\%) & $29.67+0.33$ & $29.94+0.25$ & $29.45+0.27$ \\
Crude fibre (\%) & $11.5+0.18$ & $2.65+0.29$ & $3.75+0.18$ \\
Ash (\%) & $19.15+0.19$ & $11.9+0.25$ & $21.0+0.19$ \\
NFE (\%) & $33.93+0.24$ & $32.66+0.19$ & $23.26+0.20$ \\
\hline
\end{tabular}

Table 2 Survival, SGR, FCR and PER of Cyprinus carpio fed graded levels of carrageenan incorporated diets

\begin{tabular}{llll}
\hline Parameters & \multicolumn{2}{l}{ Diets } \\
\cline { 2 - 4 } & $\mathbf{T}_{0}$ & $\mathbf{T}_{1}$ & $\mathbf{T}_{2}$ \\
\hline Survival (\%) & 73 & 76.5 & 76 \\
SGR (\% / day) & 0.86 & 0.94 & 1.23 \\
FCR & 2.50 & 2.68 & $3.3 \mathrm{I}$ \\
PER & 0.08 & 0.06 & 0.08 \\
\hline
\end{tabular}

After seven week feeding trial, enhanced weight gain was observed in fish fed on diets supplemented with 1 and $2 \%$ GrobioticAE compared to those fed the basal diet. ${ }^{9}$ The beneficial influence of Grobiotic-AE on growth was possibly due to alteration of the intestinal microflora by mannan oligo fructose, lactose from the dietary ingredient. ${ }^{9}$ Brewers yeast has been recognized to have potential as a substitute for live food in the production of certain fish. ${ }^{10}$ There was no significant difference in weight gain and specific growth rate between treatments during the feeding trial. ${ }^{11}$ Lara-Flores et al. ${ }^{12}$ investigated the effects of whole brewers yeast $S$. cerevisiae, as a probiotic on growth, body composition and digestibility of diet in fry of Nile tilapia $(O$. niloticus $)$ and found that the addition of $1 \%$ yeast to a diet with an optimum protein content $(40 \%)$ administered in low density tanks produced the best growth. No significant difference in survival and weight gain were observed among treatments when $L$. vannamei fed with sodium alginate. ${ }^{13}$ Hybrid striped bass fed the diets supplemented with $1 \%$ and $2 \%$ dried brewer's yeast had up to $20 \%$ more weight gain compared to fish fed the basal diet. ${ }^{14}$ The survival rate of shrimp improved progressively with increment of Sargassum fusiforme polysaccharide extract (SFPSE) supplemented but the individual body weight displayed a decline trend as Sargassum fusiforme polysaccharide extract (SFPSE) increased. ${ }^{15}$ Shrimp fed diets supplemented with $\geq 35 \mathrm{mg} / \mathrm{kg}$ had significantly $(\mathrm{P}<0.05)$ greater weight gain. ${ }^{16}$ The weight gain was highest in shrimp fed 75 and 100 $\mathrm{mg}$ Vitamin E $/ \mathrm{kg}$ diet. ${ }^{17}$ Survival was highest in shrimp fed $70-150$ $\mathrm{mg}$ Vitamin E / kg diet. Significantly higher weight gain (138\%) was observed in shrimp fed the diet containing $0.2 \%$ of vitamin $\mathrm{C}$ in feed and the food conversion ratio was significantly lower. ${ }^{18}$ Diet supplemented with enzyme probiotics@3 g/kg gave better weight gain, specific 
growth rate and condition factor in L. rohita fry. ${ }^{19}$ Vitamin $\mathrm{C}$ when fed at elevated level of $500 \mathrm{mg} / \mathrm{kg}$ practical diet resulted in significantly higher specific growth rate and food conversion ratio in comparison with control group of fish. Growth, specific growth rate and protein efficiency ratio were significantly better in fish fed $50 \mathrm{mg} / \mathrm{kg}$ than in the control. ${ }^{20}$ Turan \& Akyurt ${ }^{21}$ also obtained significantly higher growth in African catfish (Clarias gariepinus) fed androstenedione based diets.

It may be concluded that carrageenan, which is a carotenoid pigment used for enhancement of colour and other purposes in different animals found to enhance growth and survival of common carp when supplemented at $1 \%$ in the diet.

\section{Acknowledgments}

None.

\section{Conflicts of interest}

None.

\section{References}

1. Soderhall k, Cerenius L. Role of the Phenoloxidase activating system in invertebrates immunity. Curr Opin Immunol. 1998;10(1):23-28.

2. Murthy HS, LI Peng, Lawrence AL, et al. Dietary $\beta$-glucan and nucleotide effects on growth, survival and immune responses of pacific white shrimp, Litopenaeus vannamei. J Applied Aquaculture. 2009;21(3):160-168.

3. Shankar R, Murthy HS, Sujatha HR, et al. Effect of nucleotide on growth, immune responses and resistance of Macrobrachium rosenbergii (de Man) to Macrobrachium rosenbergii nodavirus (MrNV) and extra small virus (XSV) and Aeromonas hydrophila infection Aquacult Int. 2012;20(1):1-12.

4. Parmar PV, Murthy HS, Tejpal CS, et al. Effect of brewers yeas on immune response of giant freshwater prawn, Macrobrachium rosenbergii, and its resistance to white muscle disease. Aquacult Int. 2012;20(5):951-964.

5. Hardy R. Fish feed formulation, Paper presented at the FAO/UNDP Training course in Fish Feed Technology, Seattle WA, USA, ADCP/ REP 80.11.pp.8.1980.

6. AOAC. Official Methods of Analysis (16th edn), Harwitz W Assoc of Analytical Chemists, Washington, DC. 1995

7. Hasting WH. Fish nutrition and fish feed manufacture. FAO Technical conf on Aquaculture, Kyoto, Japan, 23 PB. 1976.

8. APHA. Standard methods for examination of water and waste water. Am Pub Hlth Assoc Washington, DC. 1995.
9. Peng Li, Delbert M, Gatlin. Dietary brewers yeast and the prebiotic Grobiotic-AE influence growth performance, immune responses and resistance of hybrid striped bass (Morone chrysops x M. saxatilis) to Streptococcus iniae infection. Aquaculture. 2004;231(1-4):445-456.

10. Nayar S, Hegde S, Rao PS, et al. Live organisms as feed in aquaculture. Infofish Int. 1998;4:36-39.

11. Ayce genc M, Erdal Yilma, Ercument Genc, et al. Effects of dietary mannan oligosaccharide on growth, body composition, intestine and liver histology of the hybrid tilapia (Oreochromis niloticus x O. aureus). The Isr J Aquac. Bamidgeh. 2007;59(1):10-16.

12. Lara-Flores M, Olvera-Novoa MA, Guzman-Mendez BE Lope Madrid W. Use of the bacteria Streptococcus faecium and Lactobacillus acidophilus and the yeast Saccharomyces cerevisiae as growth promoters in Nile tilapia (Oreochromis niloticus). Aquaculture. 2003;216(14):193-201.

13. Cheng W, Chun-Hung Liu, Ching-Ming Kuo, et al. Dietary administration of sodium alginate enhances the immune ability of white shrimp, Litopenaeus vannamei and its resistance against Vibrio alginolyticus. Fish and Shellfish Immunology. 2005;18(1):1-12.

14. Peng Li, Delbert M, Gatlin. Evaluation of brewers yeast (Saccharomyces cerevisiae) as a feed supplement for hybrid striped bass (Morone chrysops x M. saxatilis). Aquaculture. 2003;219(1-4):681-692.

15. Xuxiong Huang, Hongqi Zhou Hui Zhang. The effect of Sargassum fusiforme polysaccharide extracts on vibriosis resistance and immune activity of the shrimp, Fenneropenaeus chinensis. Fish and Shellfish immunology. 2006;20(5):750-757.

16. Shi-Yen Shiau and Lee-Chun Jiang. Dietary zinc requirements of grass shrimp, Penaeus monodon, and effects on immune responses. Aquaculture. 2006;254:476-482.

17. Lee MH, Shiau SY. Vitamin E requirements of juvenile grass shrimp, Penaeus monodon and effects on non-specific immune responses. Fish and Shellfish immunol. 2004;16(4):475-485.

18. Syama Dayal J, Gopal C, Ahamad Ali S, et al. Effect of vitamin C supplementation on growth and immune status in the juveniles of tiger shrimp, Penaeus monodon (Fabricus.) National Conference on Aquaculture Nutrition, NATP and CMFRI Kochi. 2003;12-14.

19. Mohanta KN, Subramanian S. Effect of enzyme-probiotic feed supplement on the growth performance on rohu (Labeo rohita) fry. National Conference on Aquaculture Nutrition, NATP and CMFRI Kochi. 2003;12-14.

20. Turan F, Mevlut Gurlek, Cemal Turan. Effects of dietary androstenedione concentration on growth of tilapia fry (Oreochromis aureus Linnaeus). The Isr J Aquac Bamidgeh. 2007;59(1):32-35.

21. Turan F, Akyurt I. Effects of androstenedione, a phyto androgen, on growth and body composition in the African catfish, Claria gariepinus. Isr J Aquac Bamidgeh. 2005;57(1):62-66. 